roading spectrographs and tape machines to control of a non-ferrous smelting process and to the analysis of stool work raw materials were doseribed by M. D. Amos and P. C. Thomas (Sulphide Corporation Pty., Ltd., Newcastle, N.s.W.) and by Z. Collison and 'T. Seott (Tho Broken Hill Propriotary Company, Ltd., Newcastle, N.S.W.). The use of the briquetting technique and direct readers was described by T. Scott and B. Shanley (The Broken Hill Propriotary Company, Ltd., Nowcastlo, N.S.W.) with reference to the analysis of steelworks raw materials and by K. R. Walker (Burouu of Minersal Resources, Can borra) with reforenee to tho analysis of rocks and soils. D. J. Swaine (C.S.I.R.O. Division of Coal Resoarch, Chatswood, N.S.W.) gave details of the semi-quantitativo mothods he has doveloped for tho analysis of matorials oncountered in coal research. Tho carrier distillation method for the analysis of refractory materials was used by L. S. Dalo (Australian Atomic Energy Establishmont, Lucas Heights, N.S.W.), who discussed the function of the 'carrier' in the matrix. 'The operational requirements of a small plasma jot of stablo intensity wero discussed by R. H. Brockman and R. N. Whittom (Australian Atomic Energy Establishment, Lucas Heights, N.S.W.). The final papors in tho session by $\mathbf{F}$. Broeh and $J$. Schuch (Jarrell-Ash Company, U.S.A.) described the use of a laser for vaporizing small areas of sample, tho resulting vapour boing oxcitod by a spork dischargo. The technique offers attractive possibilities as a microprobe.

D. J. David (C.S.I.R.O. Division of Plant Industry, Canberra) gave a comprehensive review of recent dovelop. ments in atomic tbsorption spectroscopy which revealed a rapidly widening accoptanco of the mothod, and he suggested that recent improvements in light sourcos and atomizors would load to sensitivities in the 'parts-perthousand-million" rango for most of the 30 oloments which are now regularly determined by atomic absorption mothods. A further 20 olomonts are now detectable at 'part-por-million' levels in incandoscont oxy-acotylene flames. J. E. Allan (Rukuhia Soil Research Station, Now Zoaland) roported results for elements having their strongest resonance lines below $2000 \AA$. For solenium the $1960 \AA$ line gives a detection limit of 0.5 p.p.m. with a hydrogen flamo. For arsenic a detection limit of I p.p.m. was obtained with tho 1890 \& lino, but the lines at 1937 and $1972 \AA$ are preferable. Experiments with tho morcury lino at $1849 \AA$ havo so far boon unsucesssful. J. V. Sullivan and A. Walsh (C.S.I.R.O. Division of Chemical Physics, Melbourne) described new atomic spectral lamps which gavo a hundrod-fold incresse in resonance line intensity compared with conventional hollow-cathodes, and also yielded more linear calibration curves. The high intonsity makes possible detection by resonance absorption and re-emission. M. D. Amos and P. E. Thomas (Sulphide Corporation Pty, Litd., Nowcastlo, N.S.W.) described a spray ohumber and burner giving improved stability and sensitivity and reported a detection limit of 0.8 p.p.m. aluminium using an oxy-acotylons flame.

C. S. Rann and A. N. Hambly (Dopartmont of Chemistry, Australian National University) reported the distribution of tho atoms of somo common metallic elements in the type of flarne commonly used in atomic absorption spoctroseopy and in a second papor roportod proliminary results on the determination of solenium. $K$. Collier and H. C. T. Stace (C.S.I.R.O. Divisions of Mathematical Statistics and Soils, Adelaido) described a statistioal mothod for dotormining the optimum condition for maximum absorption, whilo G. C. Baird and B. Envali (Defoneo Standards Laboratory, Melbourno) roportod various anion effects. The application of atomic absorption spectroscopy to the detormination of metals in alloys, paints and plistors was described by G. C. MoPhorson (John Lysaght (Aust.) I.td., Newcastle, N.S.W.) and methods for the determination of chromium, manganese and nickel in iron and steel wore reportod by $\mathrm{K}$. Kinoon and C. B. Bolcher (Tho Broken Hill Proprietary Company, Shortland, N.S.W.). G. R. Hercus (C.S.I.R.O. Division of Chemical Physics, Melbourne) discussod the possibilitios and limitations of G. $R$. Tsaak's method for the dotermination of the profiles of atomic resonance lines and $J . J$. MoNoill (C.S.I.R.O. Division of Chomical Physics, Melbourne) roported on the performance of a monochromator he had designed for manufacture in Australia, utilizing plane gratings ruled on the C.S.I.R.O. ruling ongino. A notable featuro was the particularly small amount of scattered light. Elegant mothods for automatically maintaining parallelism in interforomotor platos, or for scanning over soveral orders, wore described by J. V. Ramsey (C.S.I.R.O. Division of Physics, Sydney). This instrument also is expected to be manufacturod in Australia.

The 15 exhibitors presented a wide range of spectroscopic equipment. Of particular interest was tho exhibition for the first time at theso conferences of Australian-made oquipment, including an atomic absorption spectrophotomoter, atomic spestral lamps, a grating monochromator and microwavo-poworod Raman lamp.

At the end of this vory successful conference it was announced that the fifth Australian Spectroscopy Conference will be held in Porth in 1965.
C. IK. COOGAN
J. D. MorRison
A. WALSH
J. K. WIIMshurst

\title{
COLLAGEN RESEARCH IN CZECHOSLOVAKIA
}

\begin{abstract}
IN many ways the first International Crochoslovakian I Symposium on Collagen, held at Velké Karlovico during Septembor $2-7$, was tho most interesting meeting of its kind sinco the Cambridgo symposium of 1957 . At that timo thero was virtually no fundamental rosearch boing carried ont at C.S.S.R. institutes into connective tissuo, with the exception of $M$. Chvapil, who might bo regarded as the doyen in this field. It was the clear intention of tho organizers, comprising the food institute, the three Ifathor institutes, tho rheumatism instituto and the instituto of hygione and occupational diseases, to acquaint thoir guests with tho offort now boing directed at collagon, and there can be no doubt that tho oyos of Western obsorvers have been opened widely both to the oxtont of dotailed work now boing carried out in the C.S.S.R. and to the enthusiasm with which it is dono.
\end{abstract}

Although it cannot be said that all of this contribution is original in concopt, a very clear understanding of tho collagen field was amply demonstrated in four excellent roviow studios: "The Biosynthesis of Collagen", by J. Hurych; "Exporimental Lathyrism", by J. Rosmus; "Analysis of High Molocular Brokkdown Products of Collagn", by 7. Deyl; "The Tochnical Aspocts of Roconstituted Collagons", by C. Halómek.

It was a strong point of this morting that it was not dominated by uny single disciplino, although contributions from Sam Soiftor (Now York), H. Noda (Tokyo) and $\Lambda$. Nordwig (Munich) ensured that amino-acid sequence oxporimonts in sollagen and tochniques utilizing collagenases wero woll ropresonted. Both roconstituted collagon and the effects of ionizing radiation were major points for disenssion and these woro often linkod together; 
thus, J. Rosmus (Prague) showed that stabilizing crosslinks formed. C. Halámek (Gottwaldov) was interested in following the Highberger et al. patents for converting reconstituted collagen into leather sheet. A. Blažej (Bratislava) showed that tho X-ray diffraction pattern for collagen was destroyed by irradiation. A most noteworthy paper was given by J. Nichols (Sommorville, New Jersey) on the proparation and cross-linking of reconstituted collagen tape by co-ordinated tanning with formaldohydo and polyphenols. Electron microscopy of collagen was represented by a paper from R. Borasky (Urbana, Illinois), who regarded many of the differences shown between calf skin and shark skin fibres to be appropriated to phylogenetic studies. One gathered that there was no eloctron microscopy used in present-day collagen work in the C.S.S.R.

The paper by J. P. Bentley (Portland, Oregon) in collaboration with M. Chvapil (Prague) demonstrated the hitherto unreported oscillatory irregularity in the uptake of labelled amino-acids into collagen by guinea pig and chick embryos. It was of interest that work on rat tail tendon collagen was less prevalent than is usual at this typo of meeting. Where it did arise, several speakers pointed to the dangers of applying results obtained with this material to human conditions. Both Bentley and Vladimíra Hlaváčková (Prague) emphasized the ageing phonomenon of the collagen along the rat tail, being oldest at the proximal and most recently laid down at the distal end. There were no formal contributions on gelatin research from C.S.S.R. institutes, but A. Courts (Colworth, U.K.) reported on the influence of the molecular shape of this protein on its interaction with sulphated polysaccharides.

The medical aspects of the C.S.S.R. interests in collagen are largely those of the United Kingdom and the United.
States and include silicosis; rheumatism, in which gold therapy is being extensively studiod by M. Adam (Prague); and atherosclerosis, in which the paper by Z. Hrúza (Prague), working with subcutaneous implants of polystyrene sponges, showed the changes occurring in collagen, hexosamines and calcium on rats of different ages and as a function of diet. Now methods of arterial implantation are being used by M. Krajíček (Prague) using collagen in association with fibroplastic materials, such as dacron and terylene. It is in this surgical field that the most dramatic advances are likely to occur and may well place C.S.S.R. medico-collagen research squarely on the map.

Unfortunately it is not possible to mention all the contributors to this stimulating congress. Special commendation was reserved for Dr. E. Martin (Sommerville, New Jersoy), whose attendance was on behalf of Collagen Currents. The directors of Ethicon, Inc., who sponsor this valuable contribution to the collagen sciences, were officially thanked by Mr. Cihlár̆, the president of the congress. Full abstracts of all the papers presented are to be published in a future edition of Collagen Currents in English.

Full marks must be given to the organizers, particularly to the genius of J. Rosmus. There are certain agreeable aspects, which other committee men, whose thoughts are dwelling on conferences, might do well to contemplate. First, the size of the meeting, with seventy scientists and no concomitant sessions, seemed near to ideal conditions. Secondly, the papers were read at morning and evening sessions, with informal afternoons. Thirdly, a location was chosen well outside a large city with some recreational facilities. This was an immediate winner for creating informality, a feature which was spontaneously taken up in the discussion of papers. A. Courts

\section{HOUSE JOURNALS OF INDUSTRIAL FIRMS: THE GLAXO VOLUME}

\begin{abstract}
HE house magazines and journals produced by industrial firms and trading associations constitute a special and growing sector of scientific literature. Some organizations which are heavily dependent on research for their continued existenco find it to their advantage to issue journals containing objective commentaries on recent advances in fields of science in which they are interested. As prestige publications, these are usually woll written, with illustrations more imaginative and attractive than those to be found in original research papers.
\end{abstract}

A representative example is The Glaxo Volume*. The latest issue contains six papers by unsigned contributors. The first elaborates a remark by Sir Henry Dale, that in therapeutic science the object of biological standards is to bring about their disappearance. For after proliminary work with crude extracts of some new drug, a move develops towards a standard preparation, and then an international reference preparation. Finally, the pure substance is isolated and possibly synthesized and the drug becomes available in units of weight.

Another concise paper discusses the possibilities of cybernotics in education and therapeutic work. It refers to the mathematical analysis of the factors concerned in keeping an anti-aircraft gun on its targot, which led to the identification of a group of nerve fibres in the vertebrate motor system. The author points out that in a cybernetic sense, all animals are goal-seoking systems, as are also the control of body temperature and of the oxygen content of the blood. On this cybernetic principle a respirator has been produced for premature babies which can adjust its action to the varying needs of the

* The Glaxo Volume, 28 (Glaxo Laboratories, Ltd,, Greenford, Middlesex). child. Other machines, working on similar principles, are being used to help patients with spastic or paralysed limbs. Many more possibilities of this nature are in prospect.

A paper dealing with the sequelæ from gastric operations for ulcers of the stomach and duodenum brings out the delicate balance which exists between the organs of digestion. Operations of this kind reduce gastric mobility and the secretion of pepsin and acid. As a consequence, partially digested food passes too quickly through the duodenum and upper jejunum, so that the absorption of iron, ealcium and vitamin $B_{12}$ is diminished. It is surprising that in the short run these changes do not more often lead to serious symptoms, except under strain, the reason being that a normal body has sufficient stores of iron to last for several years, and the skeleton may lose half its stock of calcium before displaying any detectable radiological abnormality. In addition, after operations for ulcers, there is a gradual development of abnormality in the gastric mucosa, which, it is thought, may lead to the appearance of carcinoma of the stomach after a period of approximately seventeen years.

A paper on "Master Molecules", which gains much from its convincing diagrams, discusses the process in which DNA molecules make use of messenger-RNA in the synthesis of protein. This sequence is becoming fairly well understood; but the author indicates that it paves the way to the elucidation of the chemical changes involved in a mutation of DNA, towards which biochemists are now groping.

The two most far-reaching papers are concerned with antigens. It is now known that in a virus particle the protoin coat is responsible for antigenic specificity, and 